\title{
Phenotypic Characterization of Indigenous Chicken Ecotypes in Awi Zone, Ethiopia
}

\author{
Andualem Yihun ${ }^{1}$, Manzoor Ahmed Kirmani ${ }^{2}$, Meseret Molla ${ }^{3}$ \\ ${ }^{1}$ Department of Animal Science, College of Agriculture, Oda Bultum University, Chiro, Ethiopia \\ ${ }^{2}$ Department of Animal Science, College of Agriculture and Veterinary Medicine, Jimma University, Jimma, Ethiopia \\ ${ }^{3}$ Department of Animal Science, College of Agriculture and Natural Resource, University of Gonder, Gonder, Ethiopia \\ Email address: \\ andualemyihun95@gmail.com (A. Yihun),Kirmanima@gmail.com (M. A. Kirmani), meseretmo@gmail.com (M. Molla) \\ To cite this article: \\ Andualem Yihun, Manzoor Ahmed Kirmani, Meseret Molla. Phenotypic Characterization of Indigenous Chicken Ecotypes in Awi Zone, \\ Ethiopia. Ecology and Evolutionary Biology. Vol. 5, No. 4, 2020, pp. 131-139. doi: 10.11648/j.eeb.20200504.13
}

Received: October 2, 2020; Accepted: October 21, 2020; Published: November 4, 2020

\begin{abstract}
The study was conducted in three districts of Awi zone in Amhara region, with the aim to characterize and identify the phenotypic variation of indigenous chicken ecotypes. A total of 720 indigenous chicken ecotypes were (504) females and (216) males from the whole districts) to describe qualitative and quantitative traits. Local chicken were mostly normally feathered and large phenotypic variability among ecotypes was observed for plumage color. A many plumage colors were identified in all districts in which Red in high-land and mid-land and Gebsima (grayish) colours in low-land were the predominant color of the study area beside a large diversity. The average body weight of local chickens in high-land, mid-land and low-land agro-ecologies were $1.476,1.75$ and $1.71 \mathrm{~kg}$ respectively, while the respective values for mature cocks and hens were 1.78 and $1.51 \mathrm{~kg}$. Variations were also observed in shank length, chest circumference, body length, neck length, wingspan, wing length, comb width, comb length and shank circumference. In conclusion, there is diversity of indigenous chicken population and farmers' preference of different traits that may invite to design community based genetic improvement. These were recommended in poultry breeding policy which focused on managemental system, selection, and trait preference should be designed.
\end{abstract}

Keywords: Characterization, Morphology, Production Environment

\section{Introduction}

Poultry is the largest livestock group in the world estimated to be about 23.39 billion, consisting mainly; chickens, ducks and turkeys [1]. Ethiopia is believed to have the largest livestock population. According to [2], there are about 56.53 million chickens in Ethiopia, comprising of $94.31,3.21$ and $2.49 \%$ of indigenous, hybrid and exotic types, respectively. Phenotypic characterization of Animal Genetic Resources (AnGR) generally refers to the process of identifying distinct breed populations and describing their external and production characteristics within a given production environment [3]. The term "breed" is used in phenotypic characterization to identify district Animal Genetic Resources (AnGR) populations as units of phenotypic reference and measurement.

Characterization is the initial step for long-term genetic improvement as it provides the basis for any other livestock development interventions and provides information for designing appropriate breeding programs [4]. Phenotypic characterization of breed includes all activities related with the description of the source, development, structure, and populations of quantitative and qualitative characteristics in the defined climatic condition [3]. Furthermore, characterization can identify breeds and/or populations which are at risk of extinction or which are highly desired by farmers, and hence is an important input into nation's chicken development planning [5].

No such characterization studies have been carried out to characterize and classify the existing local chicken Ecotypes in these area, in general the study districts in particular (Faggeta lekoma, Dangila and Zigom) districts. Given the highest potential for poultry production and presence of diverse ecotypes, it is imperative to conduct comprehensive studies to characterize morphological, functional, and 
adaptive traits of local chickens. Therefore, the objective of this study was to identify and characterize the new local chicken ecotypes in Awi zone, Ethiopia.

\section{Material and Methodology}

The study was conducted in Faggeta lekoma, Dangila and Zigom districts of Awi Zone based on their altitude classification into three agro-ecologies of Awi zone, Amhara regional state, Ethiopia. The administrative centre of Awi zone is Injibara; other towns include Chagni, Adis kidame, jawi, gimjabet, ----Dangila. Topographically, Awi zone is relatively flat: the altitude of the zone ranges from as low as 550 to 3100 m.a.s.l and the Minimum and maximum annual temperature ranges between $5^{\circ} \mathrm{C}$ and $27^{\circ} \mathrm{C}$. Daily temperature becomes very high during the months of March to May. Average mean annual rainfall for the area is about $1700 \mathrm{~mm}$. The study site is presented in figure 1 .

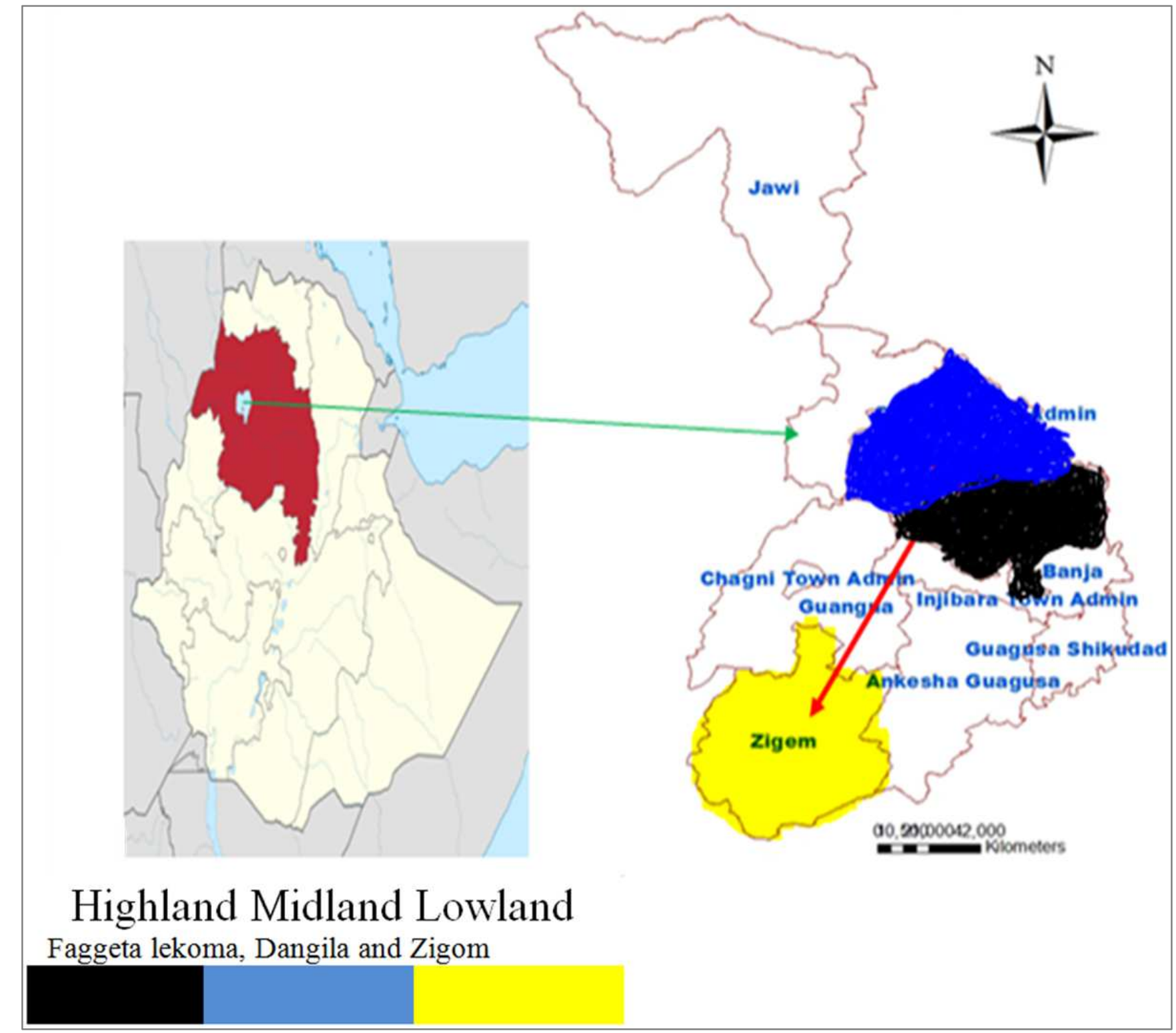

Figure 1. Location of the study site.

The Zone is crossed by about nine permanent rivers which drain into the Blue Nile; Awi Zone has Two crater lakes namely, Zengena and Tirba. Awi zone has 1,231,447 cattle, 676,509 sheep, 162,576 goats, 206,035 equine (Horse 96,136, Donkey 93,052, mule 16,667), 1,151,708 poultry and 128,906 bee colonies [2]. The Samples were conducted from three districts, Faggeta lekoma, Dangila and Zigom.

\subsection{Sample Size Determination and Sampling Technique}

The study was conducted in Faggeta lekoma, Dangila and Zigom districts of Awi zone.

Purposive sampling was employed to select districts based on distribution of chicken population and Agro-ecological variations. Thus, three sample districts and six rural Kebeles ( 2 from each district) were selected for the study. The 
numbers of sampled households and total populations in the study area were determined by the formula described by [6]

$$
\mathrm{No}=\frac{\mathrm{Z}^{2} *(\mathrm{p})(\mathrm{q})}{\mathrm{e}^{2}}
$$

Where no $=$ required sample size

$\mathrm{Z}^{2}=$ is the abscissa of the normal curve

$\mathrm{e}^{2}=$ is the margin of error (eg. $\pm 0.05 \%$, margin of error for confidence level of $95 \%$ )

$\mathrm{p}=$ is the degree of variability in the attributes being measured refers to the distribution of attributes in the population $\mathrm{q}=1-\mathrm{p}$.

$$
\text { No }=\frac{Z^{2} *(p)(q)}{e^{2}}
$$

$$
\begin{aligned}
& =1.96^{2} \times(0.136)(0.864) \div(0.05)^{2} \\
& =3.8416 \times(0.136)(0.864) \div 0.0025 \\
& =180.56-180
\end{aligned}
$$

The numbers of total population of chicken per single district was determined as below formula:

$$
\begin{aligned}
& \text { no }=\frac{\mathrm{Z}^{2} *(\mathrm{p})(\mathrm{q})}{\mathrm{e}^{2}} \\
& \mathrm{~N}=(1.96)^{2} \times(0.194)(0.806) \div(0.05)^{2} \\
& \mathrm{~N}=3.8416 \times 0.194 \times 0.806 \div 0.0025 \\
& \mathrm{~N}=240.275 * 240
\end{aligned}
$$

This is for one district, for the three districts $3 \times 240=720$. Therefore totally 720 indigenous chickens used for collecting data of quantitative and qualitative traits.

Table 1. Sampled house hold and chicken sample in the study area.

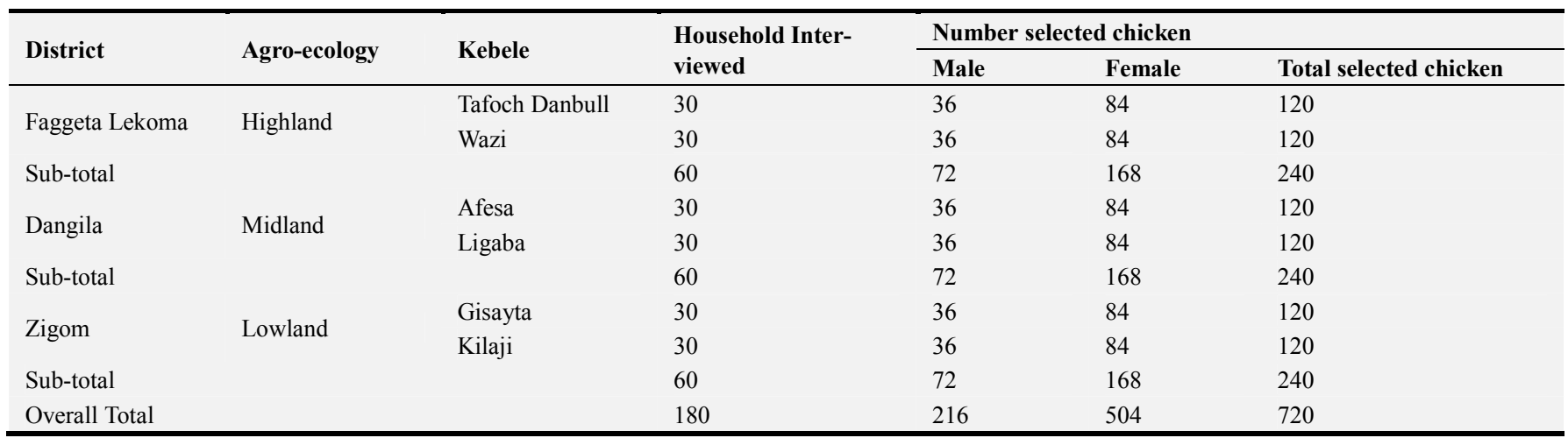

\subsection{Data Collection Procedure}

For this study, primary data sources were used. In order to collect primary data, the Participatory Rural Appraisal (PRA) involves local communities as active analysts of their own situations where they estimate, quantify, compare and list priorities of resources and constraints of poultry based on their circumstances.

Data generated by the actual recording of linear body measurements (such as; body weight, shank length, earlobe length, body length, wing span, chest circumference, comb length, comb width, beak length, wing length, neck length, wattle length, shank Circumference, wattle width) and Qualitative data such as plumage color, comb type, feather distribution, shank colour, earlobe color, eye colour, beak colour, comb colour, shank feather and head shape was gathered based on standard format breed descriptor list [3].

\subsection{Data Management and Analysis}

Both the qualitative and quantitative data were entered into Microsoft EXCEL. Simple descriptive statistics such as average and standard error of the mean were applied for quantitative data, or frequencies and tabulations for qualitative attributes. And chi-square was used to compare variables for significantly or not across the three agro- ecologies. Multivariate analyses variance technique was applied to determine the most interesting traits from a set of traits, in order to differentiate chicken population based on their nature of similarity. The results of the analysis of the data were presented as tables.

\subsection{Quantitative Data}

A general linear model procedure (PROC GLM) of the SAS was employed for quantitative variables to detect statistical differences among sampled indigenous chicken populations. For mature animals, agro-ecology and sex of the experimental indigenous chickens are fitted as fixed variables. The effects of class variables and their interaction is expressed as Least Square Means (LSM) \pm SE. Mean comparisons of significant differences were carried out using Tukey test (studentized range test) method at $\mathrm{p}<0.05$. The following Model was used for the least - squares analysis of local chicken.

$$
\mathrm{Y}_{\mathrm{ijk}}=\mu+\mathrm{A}_{\mathrm{i}}+\mathrm{S}_{\mathrm{j}}+\mathrm{AS}_{\mathrm{ij}}+\mathrm{E}_{\mathrm{ijk}}
$$

Where:

$\mathrm{Y}_{\mathrm{ijk}}=\mathrm{k}^{\text {th }}$ observation under $\mathrm{j}^{\text {th }}$ sex and $\mathrm{i}^{\text {th }}$

Agro-ecology (Observed body weight or linear measurements)

$\mu=$ Overall mean

$A_{i}=$ Fixed effect of $i^{\text {th }}$ agro-ecology $(I=$ High-Land, Mid- 
Land and Law-Land)

$S_{j}=$ Fixed effect of $j^{\text {th }} \operatorname{sex}(j=$ Male and Female)

$\mathrm{AS}_{\mathrm{ij}}=$ agro-ecology \& sex interaction effect

$\mathrm{E}_{\mathrm{ijk}}=$ Residual error corresponding to $\mathrm{E}_{\mathrm{ijk}}$

\section{Result and Discussion}

\subsection{Phenotypic Characteristics of Local Chicken}

The results on phenotypic (morphological) characterization of local chicken in the study areas were presented in Table 2 and figure 2 The phenotypic characterization was studied in terms of feather distribution, plumage colour, beak colour, eye colour, comb shape, comb colour, head shape, earlobe colour, shank colour and shank feather. The results are discussed as under:

(a) Feather Distribution and Plumage Colour

The results showed that local chicken were either normal feathered or necked neck. Out of these two-feather distributions, normal feathering was more numerous as indicated by proportion of birds $(70,59.2,53.8 \%$ for female birds and 30, 28.3, 25\% for male birds in Highland, Midland and Lowland agro-ecologies, respectively). The naked-neck genotype is characterized by featherless skin on the neck and on the breast part of the body [7]. Similarly, the naked-neck traits found in indigenous chicken population of the tropics considered to have desirable effect on heat tolerances [8]. The results showed that the plumage colours were red, white, black, gebsima, Tetrima and multi-colour. Out of these colours, red plumage colour was more numerous in both male and female birds in Highland $(28.8,20.2)$ female and male, in Midland $(29.6,19.2)$ female and male and in Lowland (19.2, 17.9\%) in female and male birds, respectively). In Lowland red plumage colour was more numerous in only male $(17.9 \%)$ birds where as in female birds gebsima was more numerous $(24.6 \%)$.

This result was comparable with [9] who reported that chicken having red $(26.9 \%)$ white $(15.60 \%)$, gebsima (greyish) (14.2\%) and black (11.5\%) plumage colour were predominately found in North Gonder. However, this result is not in line with [10] who reported that white (19.5\%), black $(11.33 \%)$, and black with white stripes $(10.17 \%)$ and dira (red wheaten) were the most predominant colour type was reported.

(b) Eye Colour and Beak Colour

The various eye colours exhibited by the local chicks were red, orange, brown and blue. The overall percentages of orange, red, brown and blue eye color of chicken in all agroecologies were $39.3,36.00,22.50$ and $1.90 \%$ in the present study. The results showed that orange eye colour was more numerous in females in the three agro-ecologies $(28.3,32.5$, $29.2 \%$ in Highland, Midland and Lowland agro-ecologies, respectively); whereas in males red eye colour was more numerous in Highland (13.8\%) and Lowland (16.3\%) agroecologies. However, orange eye colour was more numerous in Midland (13.3\%).

The study showed that local chicks showed white, yellow and brown beak colour. The white beak colour was more numerous in Highland $(33.3,17.1 \%$ in female and male birds, respectively); in Midland yellow was more numerous in females $(27.5 \%)$ whereas white was more numerous in males $(13.8 \%)$; in Lowland females had white beak colour in more birds (26.7\%) and male had more yellow beak colour $(11.7 \%)$. The results also showed that white, yellow and brown proportions were generally number one, two and three in descending order of proportions.

(c) Comb Shape and Comb Colour

Regarding comb types rose, pea and single comb types was observed in all agro-ecologies. The rose comb type was predominant in all agro-ecologies followed by pea and single. The overall average proportion of rose, pea and single combs were $52.78 \%, 30.97 \%$ and $16.25 \%$ in present study. The comb colours observed in the studied population were red, brown and black. The dominant comb color was red 95.69\% (Overall proportions) whereas the remaining $2.77 \%$ and $1.54 \%$ proportion (Overall) of studied birds had brown and black comb colors, respectively. The red comb colour was more numerous in all agro-ecologies. This result was similar with [10] who reports that commonest comb color observed was red (hens 95\%, cocks 97\%), whereas the remaining $5 \%$ of hens and $3 \%$ of cocks showed brown and black colors in Centeral Tigray.

(d) Head Shape and Earlobe Colour

The study of head shapes showed that local chicken had either plain or crest head shape. Out of these two shapes, the plain head shapes was more common in both sexes in all agro-ecologies $(40.00,20.40 \%$ in female and male in Highland; $36.30,20.80 \%$ in females and males in Midland; $50.00,23.8 \%$ in female and males in Lowland agroecologies). The overall mean values of head shapes were $63.75 \%$ plain head and $36.25 \%$ crest. This result agreed with [11] who reported $72.8 \%$ and $27.2 \%$ were plain and crest headed shape in Southwest Oromia and Gurage zone.

The earlobe colours found in the studied populations were either white or red or mixture of red + white olours. The overall proportion of earlobe colour showed that $36.30,32.20$ and $31.50 \%$ of birds had mixture of red+white, red and white colours. This result was more or less comparable to those of [12] who reported that red and white earlobes showed $41.4 \%$ and $49.5 \%$ in Horro and Jarso ecotypes, respectively and also close to the reports of [13] for Fogera chicken.

(e) Shank Colour and Shank Feather

Most of the indigenous chickens evaluated in scavenging management systems in the study area showed white (45.97\%), yellow (33.6\%), brown (17.08\%), red $(2.36 \%)$ and black $(0.97 \%)$ shank colour (Overall proportions) were exhibited by these birds. This result was comparable with the findings of [10] who reported that yellow shank colour $(41.17 \%)$ was dominant over white $(19.83 \%)$ and black $(15.5 \%)$ shank colours in Centeral Tigray. Similarly, a study conducted in districts of North West Ethiopia also revealed that most indigenous chickens had yellow, white, red, black and grey shank colours by [5]. The results on presence / absence of shank feathers showed that all studied chickens in 
mid-land and low-land agro-ecology were not having shank feather in Highland agro-ecologies in the present study. feather whereas only $2.5 \%$ hen and $1.67 \%$ cock had shank

Table 2. Phenotypic (Morphological) Characterization of Local Chicken in the Study Areas.

\begin{tabular}{|c|c|c|c|c|c|c|c|}
\hline \multirow{4}{*}{ Variables } & \multicolumn{6}{|c|}{ Agro-ecologies } & \multirow{3}{*}{$\begin{array}{l}\text { Over-all } \\
\text { Mean }\end{array}$} \\
\hline & \multicolumn{2}{|c|}{ Highland } & \multicolumn{2}{|l|}{ Midland } & \multicolumn{2}{|l|}{ Lowland } & \\
\hline & Female & Male & Female & Male & Female & Male & \\
\hline & $\%$ & $\%$ & $\%$ & $\%$ & $\%$ & $\%$ & $\%$ \\
\hline \multicolumn{8}{|l|}{ (I) Feather distribution } \\
\hline Normal & 70 & 30 & 59.2 & 28.3 & 53.8 & 25 & 88.8 \\
\hline Necked-Neck & - & - & 10.8 & 1.7 & 16.3 & 5 & 11.2 \\
\hline $\begin{array}{l}\mathrm{X}^{2} \text { value/ P value } \\
\text { (II) Plumage colour }\end{array}$ & & & & $5.4 / 0.00$ & & & \\
\hline Red & 28.8 & 20.2 & 29.6 & 19.2 & 16.2 & 17.9 & 43.2 \\
\hline White & 3.3 & 1.7 & 5 & 1.3 & 2.9 & 0.4 & 4.9 \\
\hline Black & 3.8 & 0.4 & 3.3 & 0.4 & 4.2 & - & 4 \\
\hline Gebsima & 16.3 & 6.3 & 17.3 & 2.5 & 24.6 & 7.5 & 26.5 \\
\hline Tetrima & 9.2 & 4.6 & 7.1 & 2.9 & 14.6 & 3.3 & 13.9 \\
\hline Multi-colour & 8.8 & 0.4 & 7.9 & - & 4.6 & 0.8 & 7.5 \\
\hline $\mathrm{X}^{2}$ value/ $\mathrm{P}$ value & & & & $4.46 / 0.00$ & & & \\
\hline \multicolumn{8}{|l|}{ (III) Eye colour } \\
\hline Red & 24.6 & 13.8 & 20 & 10.4 & 23.3 & 16.3 & 36.00 \\
\hline Orange & 28.3 & 7.1 & 32.5 & 13.3 & 29.2 & 7.9 & 39.30 \\
\hline Brown & 15.4 & 8.8 & 14.6 & 5.4 & 17.5 & 5.8 & 22.50 \\
\hline Blue & 1.7 & 0.4 & 2.9 & 0.8 & - & - & 1.90 \\
\hline $\mathrm{X}^{2}$ value/ $\mathrm{P}$ value & & & & $6.89 / 0.000$ & & & \\
\hline \multicolumn{8}{|l|}{ (IV) Beak colour } \\
\hline White & 33.3 & 17.1 & 26.7 & 13.8 & 26.7 & 10.8 & 42.8 \\
\hline Yellow & 27.9 & 8.3 & 27.5 & 11.7 & 25.8 & 11.7 & 37.6 \\
\hline Brown & 8.8 & 4.6 & 15.8 & 4.6 & 17.5 & 7.5 & 19.6 \\
\hline $\mathrm{X}^{2}$ value/ $\mathrm{P}$ value & & & & $3.5 / 0.000$ & & & \\
\hline \multicolumn{8}{|l|}{ (V) Comb shape } \\
\hline Rose & 34.2 & 18.3 & 40.4 & 20.8 & 27.5 & 17.08 & 52.8 \\
\hline Pea & 24.2 & 10 & 20.8 & 7.1 & 22.1 & 8.8 & 30.9 \\
\hline Single & 11.7 & 1.7 & 8.8 & 2.1 & 20.4 & 4.2 & 16.3 \\
\hline $\mathrm{X}^{2}$ value/ $\mathrm{P}$ value & & & & $8.61 / 0.000$ & & & \\
\hline \multicolumn{8}{|l|}{ (VI) Comb colour } \\
\hline Red & 67 & 29.2 & 67.1 & 28.3 & 65 & 28.8 & 95.7 \\
\hline Brown & 1.3 & - & 1.3 & 1.67 & 3.3 & 0.8 & 2.8 \\
\hline Black & 1.7 & 0.8 & - & - & 1.7 & 0.4 & 1.6 \\
\hline \multicolumn{7}{|l|}{ (VII) Head shape } & \\
\hline Plain & 40 & 20.4 & 36.3 & 20.8 & 50 & 23.8 & 63.75 \\
\hline Crest & 30 & 9.6 & 33.8 & 9.2 & 20 & 6.3 & 36.25 \\
\hline $\mathrm{X}^{2}$ value/ $\mathrm{P}$ value & & & & $16.43 / 0.000$ & & & \\
\hline \multicolumn{8}{|l|}{ (VIII) Earlobe colour } \\
\hline White & 15.42 & 14.6 & 20 & 15 & 15.8 & 13.8 & 31.5 \\
\hline Red & 25.83 & 3.3 & 24.6 & 5.8 & 30.8 & 6.3 & 32.2 \\
\hline White \& Red & 28.8 & 12.1 & 25.4 & 9.2 & 23.3 & 10 & 36.3 \\
\hline $\mathrm{X}^{2}$ value/ $\mathrm{P}$ value & & & & $15.2 / 0.000$ & & & \\
\hline \multicolumn{8}{|l|}{ (IX) Shank colour } \\
\hline Yellow & 27.5 & 6.3 & 23.3 & 6.7 & 24.6 & 12.5 & 33.6 \\
\hline White & 25.8 & 17.1 & 30.8 & 20 & 31.7 & 12.5 & 45.9 \\
\hline Brown & 13.8 & 4.6 & 12.1 & 2.1 & 13.8 & 5 & 17.1 \\
\hline Red & 2.9 & 1.3 & 2.5 & 0.4 & - & - & 2.4 \\
\hline Black & - & 0.8 & 1.3 & 0.8 & - & - & 0.9 \\
\hline $\mathrm{X}^{2}$ value/ $\mathrm{P}$ value & & & & & $4.11 / 0.000$ & & \\
\hline \multicolumn{8}{|l|}{ (X) Shank feather } \\
\hline \multicolumn{8}{|c|}{ Absence 67.528 .37030703096 .6} \\
\hline \multicolumn{8}{|c|}{ Presence 2.51 .7 - - - 1.4} \\
\hline $\mathrm{X}^{2}$ value/ $\mathrm{P}$ value 2.8 & & & & & & & \\
\hline
\end{tabular}




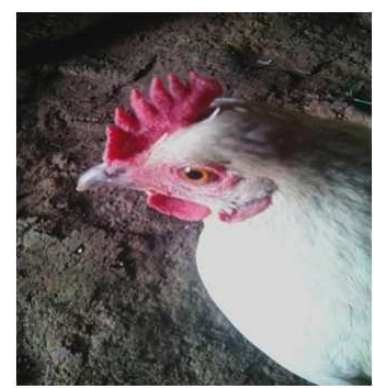

White Plumage, single comb, yellow eye colour, and brown beak colour

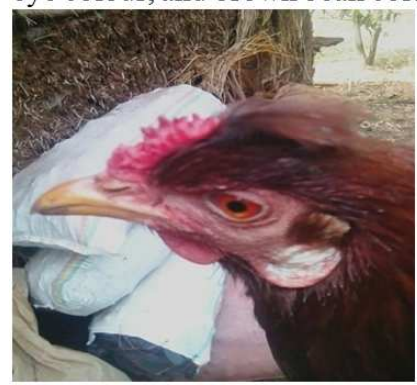

Red plumage, white \& red earlobe colour, yellow beak crest head shape

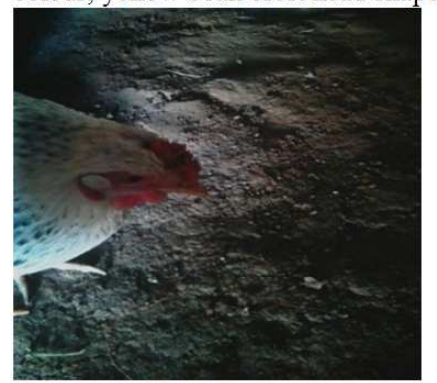

Tetrima (white with black) plumage and black eye colour

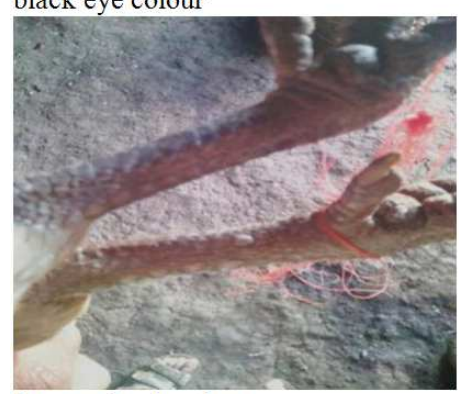

Brown shank colour

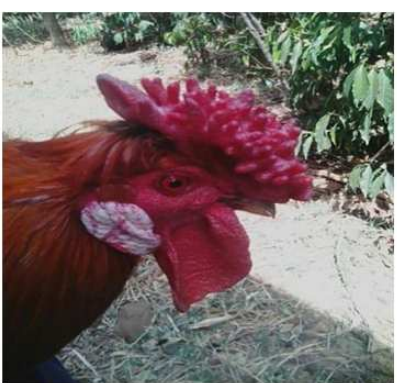

Red Plumage, pea comb, white/some red ear lobe, red eye colour

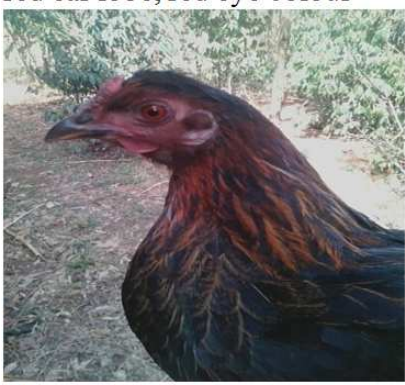

Black with some red plumage black beak colour and plain head shape

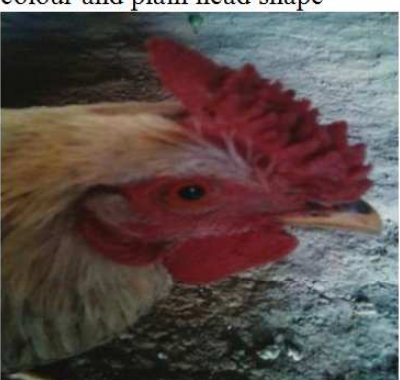

Multi-plumage, black eye colour and Rose comp

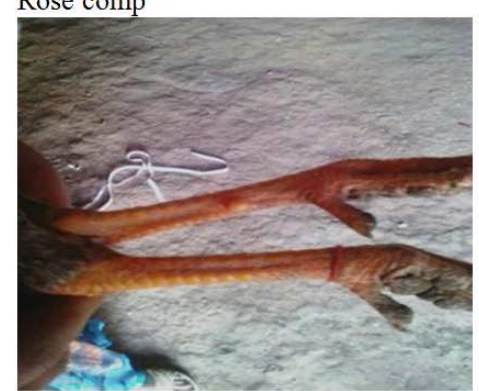

Red shank colour

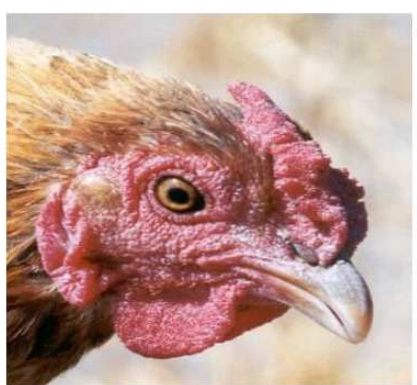

Multi-colour plumage, rose comb, yellow beak, red earlobe

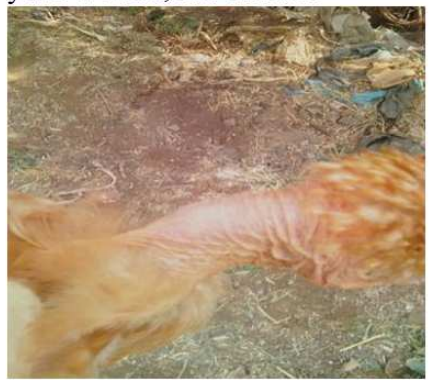

Gebsima plumage colour necked- neck

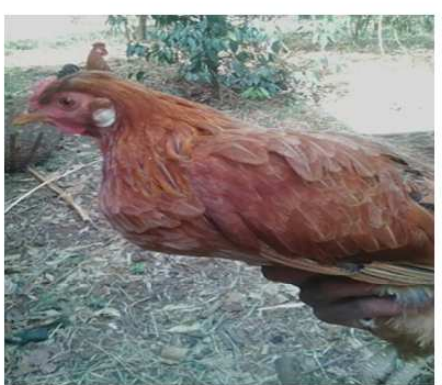

red plumage, white earlobe colour yellow beak colour

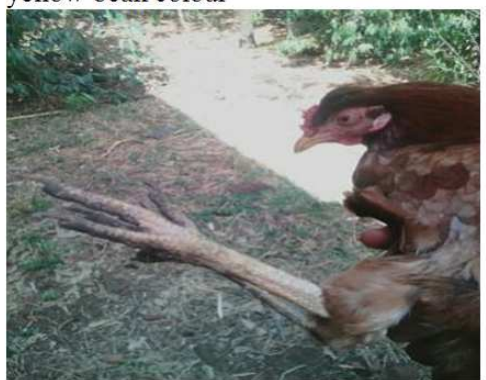

White shank colour

Figure 2. Phenotypic Variation of Indigenous Chicken.

\subsection{Quantitative Traits}

The quantitative traits studied were Bwt (Body weight), Bl (Body length), $\mathrm{Cl}$ (Comb length), $\mathrm{Cw}$ (Comb width), $\mathrm{Ww}$ (Wattle width), Ws (Wingspan), Bel (beak length), Wl (Wattle length), Cc (Chest circumference), El (Ear lope length), Sl (Shank length), Sc (Shank circumference), N1 (Neck length), and Wil (wing length) in the present study. The least square ANOVA for agro-ecologies, sex and interaction between sex $\mathrm{X}$ agro-ecologies was presented in the least square means of these traits was presented in Tables 3,4 and 5 .

(a) Agro-ecology Effect
The least square mean showed that AEGs significantly $(\mathrm{P}<0.05)$ influenced all quantitative traits studied except $\mathrm{Bl}$, $\mathrm{Cl}, \mathrm{Ww}, \mathrm{Bel}, \mathrm{Wl}$ and $\mathrm{El}$. The least square mean values of body weight, wing length, shank length, shank circumference, and chest circumference, were significantly $(p<0.05)$ maximum in mid-land chicken but wing span and neck length were higher in low-land.

(b) Sex Effect

The least square mean showed that sex significantly $(\mathrm{P}<0.05)$ influenced all quantitative traits studied except $\mathrm{Ww}$, $\mathrm{Sc}$ and Bel. The results showed that there was wide variation in these quantitative traits between two sexes. The average measurement parameters of female and male indigenous 
chickens were $1.51 \mathrm{~kg} \& 1.78 \mathrm{~kg}$ for body weight, $35.26 \mathrm{~cm} \&$ $36.23 \mathrm{~cm}$ for body length, $2.08 \mathrm{~cm} \mathrm{\&} 2.82 \mathrm{~cm}$ for comb length, $9.007 \& 9.86$ for shank length, $3.44 \& 3.49$ for shank circumference, $11.65 \& 12.34$ for neck length, $11.99 \& 12.84$ for wing length, $36.96 \& 38.16$ for wing span, $2.05 \& 2.44$ for wattle length and $26.59 \& 27.53$ for chest circumference in female and male local chickens, respectively.

The sex differences in live weight and most of the LBMs, observed in this study, showed that these parameters are sex dependent. The cocks had consistently higher measurement value than hens across all the significantly affected variables except some variables, that was not significant $(p<0.05)$.

The possible reason for higher values of studied quantitative traits in males (Cocks) might be ascribed to the effect of sex hormones, stress on hens during egg formation/ laying and brooding time (which reduce period spent on feeding/ scavenging). The present results were in good agreement with the report of $[5,4,14]$ who stated that male chickens had better performance than females. These differences was also agreement with [12] in Jarso and Horro; [13] in Fogera; [5] in Northwest Ethiopia; and [14]; from North Gonder who reported that differences between sexes may be due to the differential effects of androgens and estrogens hormones on growth.

(c) Interaction Effect

There was no significant $(\mathrm{P}<0.05)$ interaction observed between agro-ecologies and sexes with respect to quantitative traits studied except for comb length and wattle length. In these traits higher measurements were mostly observed in mid-land and low-land as compare to high-land. The significant interaction between agro-ecology and sexes with respect to these morphmetric traits might be due to the differences between the three agro-ecologies with respect to the degree of expression of sex dimorphism for the traits.

Table 3. Least Square Means for Body Weight ( $\mathrm{kg}$ ) and Body length, comp length, comp width wattle width Measurements are in (cm) of Local Chickens.

\begin{tabular}{llllll}
\hline \multirow{2}{*}{ Effect Trait } & Traits & & & \\
\cline { 2 - 6 } & Bwt (kg) & Bl (cm) & Cl (cm) & Cw $\mathbf{( c m )}$ & Ww (cm) \\
\hline Overall & $1.59 \pm 0.02$ & $35.55 \pm 0.06$ & $2.29 \pm 0.02$ & $2.26 \pm 0.02$ & $2.24 \pm 0.02$ \\
$\mathrm{R}^{2}$ & 0.18 & 0.08 & 0.67 & 0.64 & 0.52 \\
Cv\% & 2.45 & 4.38 & 9.79 & 9.53 & 12.49 \\
Agro-ecology & $*$ & $\mathrm{Ns}$ & $\mathrm{ns}$ & $*$ & $\mathrm{~ns}$ \\
Highland & $1.48 \pm 0.01 \mathrm{~b}$ & $35.77 \pm 0.14$ & $2.46 \pm 0.04$ & $2.42 \pm 0.01 \mathrm{a}$ & $2.38 \pm 0.02 \mathrm{a}$ \\
Midland & $1.75 \pm 0.02 \mathrm{a}$ & $35.84 \pm 0.13$ & $2.44 \pm 0.049$ & $2.39 \pm 0.01 \mathrm{a}$ & $2.06 \pm 0.2 \mathrm{~b}$ \\
Lowland & $1.71 \pm 0.02 \mathrm{a}$ & $35.62 \pm 0.12$ & $2.39 \pm 0.04$ & $2.28 \pm 0.01 \mathrm{~b}$ & $2 \pm 0.02 \mathrm{~b}$ \\
SEX & $*$ & $*$ & $*$ & & $\mathrm{~ns}$ \\
Female & $1.51 \pm 0.02^{\mathrm{b}}$ & $35.26 \pm 0.07^{\mathrm{b}}$ & $2.08 \pm 0.02^{\mathrm{b}}$ & $2.06 \pm 0.01^{\mathrm{b}}$ & $2.06 \pm 0.09$ \\
Male & $1.78 \pm 0.02^{\mathrm{a}}$ & $36.24 \pm 0.12^{\mathrm{a}}$ & $2.78 \pm 0.02^{\mathrm{a}}$ & $2.45 \pm 0.02^{\mathrm{a}}$ & $2.73 \pm 0.02$ \\
Sex*AEGs interaction & Ns & $\mathrm{Ns}$ & $*$ & $\mathrm{~ns}$ & $\mathrm{~ns}$ \\
HL x Female & $1.36 \pm 0.02$ & $35.24 \pm 0.12$ & $2.06 \pm 0.01$ & $2.06 \pm 0.02$ & $2.23 \pm 0.02$ \\
HL x male & $1.68 \pm 0.03$ & $36.23 \pm 0.17$ & $2.87 \pm 0.03$ & $2.49 \pm 0.03$ & $2.42 \pm 0.002$ \\
ML x Female & $1.59 \pm 0.03$ & $35.27 \pm 0.12$ & $2.17 \pm 0.02$ & $2.08 \pm 0.02$ & $2.15 \pm 0.023$ \\
ML x male & $1.85 \pm 0.04$ & $36.27 \pm 0.17$ & $2.71 \pm 0.03$ & $2.46 \pm 0.03$ & $2.58 \pm 0.03$ \\
LL x Female & $1.61 \pm 0.03$ & $35.26 \pm 0.13$ & $2.05 \pm 0.02$ & $2.05 \pm 0.02$ & $1.9 \pm 0.01$ \\
LL x male & $1.82 \pm 0.04$ & $36.25 \pm 0.17$ & $2.75 \pm 0.03$ & $2.41 \pm 0.03$ & $2.4 \pm 0.02$ \\
\hline
\end{tabular}

Table 4. Least Square Means for Wing span, Beak length, wattle length, Comb length and Ear length Chickens.

\begin{tabular}{|c|c|c|c|c|c|}
\hline \multirow{2}{*}{ Effect } & \multicolumn{5}{|l|}{ Traits } \\
\hline & Ws (cm) & Bel (cm) & Wl (cm) & Cc (cm) & EI (cm) \\
\hline Overall & $37.32 \pm 0.07$ & $2.25 \pm 0.03$ & $2.17 \pm 0.09$ & $26.87 \pm 0.06$ & $1.76 \pm 0.04$ \\
\hline $\mathrm{R}^{2}$ & 0.19 & 0.02 & 0.52 & 0.12 & 0.12 \\
\hline CV (\%) & 4.25 & 3.95 & 5.23 & 5.36 & 2.29 \\
\hline Agro ecology & $*$ & Ns & ns & $*$ & ns \\
\hline Highland & $36.85 \pm 0.1^{\mathrm{b}}$ & $2.24 \pm 0.02$ & $2.29 \pm 0.02$ & $26.75 \pm 0.09 b$ & $1.84 \pm 0.02$ \\
\hline Midland & $37.89 \pm 0.02^{\mathrm{a}}$ & $2.25 \pm 0.02$ & $2.25 \pm 0.01$ & $27.27 \pm 0.07 \mathrm{a}$ & $1.82 \pm 0.02$ \\
\hline Lowland & $37.94 \pm 0.01 \mathrm{a}$ & $2.24 \pm 0.04$ & $2.19 \pm 0.01$ & $27.15 \pm 0.06 \mathrm{ab}$ & $1.85 \pm 0.02$ \\
\hline Sex & * & Ns & * & * & $*$ \\
\hline Female & $36.96 \pm 0.1 b$ & $2.24 \pm 0.01$ & $2.05 \pm 0.08 \mathrm{~b}$ & $26.59 \pm 0.06 \mathrm{~b}$ & $1.68 \pm 0.06 b$ \\
\hline Male & $38.26 \pm 0.01 a$ & $2.25 \pm 0.02$ & $2.44 \pm 0.01 \mathrm{a}$ & $27.53 \pm 0.09 a$ & $1.96 \pm 0.02 \mathrm{a}$ \\
\hline Sex*AEGs interaction & $\mathrm{Ns}$ & Ns & $*$ & ns & ns \\
\hline HL x Female & $36.13 \pm 0.12$ & $2.24 \pm 0.02$ & $2.1 \pm 0.01$ & $26.12 \pm 0.10$ & $1.70 \pm 0.03$ \\
\hline HL x male & $37.59 \pm 0.18$ & $2.24 \pm 0.01$ & $2.5 \pm 0.02$ & $27.38 \pm 0.16$ & $1.98 \pm 0.04$ \\
\hline ML x Female & $37.31 \pm 0.17$ & $2.25 \pm 0.02$ & $2.03 \pm 0.01$ & $26.81 \pm 0.11$ & $1.66 \pm 0.03$ \\
\hline ML x male & $38.47 \pm 0.19$ & $2.25 \pm 0.02$ & $2.5 \pm 0.02$ & $27.74 \pm 0.17$ & $1.89 \pm 0.04$ \\
\hline LL $x$ Female & $37.64 \pm 0.18$ & $2.24 \pm 0.01$ & $2.02 \pm 0.01$ & $26.83 \pm 0.11$ & $1.68 \pm 0.03$ \\
\hline LL $x$ male & $38.43 \pm 0.19$ & $2.25 \pm 0.02$ & $2.4 \pm 0.02$ & $27.47 \pm 0.16$ & $2.10 \pm 0.04$ \\
\hline
\end{tabular}


Table 5. Least Square Means for Shank length, Shank circumference, Nick length and Wing length of Local Chickens.

\begin{tabular}{|c|c|c|c|c|}
\hline \multirow{2}{*}{ Effect } & \multicolumn{4}{|l|}{ Trait } \\
\hline & SI (cm) & Sc (cm) & $\mathrm{NI}(\mathrm{cm})$ & Wil (cm) \\
\hline \multicolumn{5}{|l|}{ Trait } \\
\hline Overall & $9.26 \pm 0.05$ & $3.46 \pm 0.02$ & $11.85 \pm 0.04$ & $12.25 \pm 0.06$ \\
\hline $\mathrm{R}^{2}$ & 0.16 & 0.14 & 0.28 & 0.15 \\
\hline CV (\%) & 12.66 & 7.39 & 6.73 & 11.27 \\
\hline Agro-ecology & $*$ & $*$ & $*$ & $*$ \\
\hline Highland & $9.02 \pm 0.02 b$ & $3.47 \pm 0.05 \mathrm{ab}$ & $11.71 \pm 0.02 \mathrm{~b}$ & $11.96 \pm 0.02 b$ \\
\hline Midland & $9.61 \pm 0.03 \mathrm{a}$ & $3.62 \pm 0.05 \mathrm{a}$ & $12.07 \pm 0.03 a b$ & $12.94 \pm 0.03 \mathrm{a}$ \\
\hline Lowland & $9.59 \pm 0.03 \mathrm{a}$ & $3.29 \pm 0.05 b$ & $12.12 \pm 0.03 \mathrm{a}$ & $12.36 \pm 0.04 \mathrm{ab}$ \\
\hline Sex & $*$ & Ns & $*$ & $*$ \\
\hline Female & $9.10 \pm 0.05 b$ & $3.44 \pm 0.01$ & $11.65 \pm 0.047 \mathrm{~b}$ & $11.99 \pm 0.06 \mathrm{~b}$ \\
\hline Male & $9.95 \pm 0.08 a$ & $3.65 \pm 0.016$ & $12.34 \pm 0.07 \mathrm{a}$ & $12.64 \pm 0.09 \mathrm{a}$ \\
\hline Sex*AEGs interaction & Ns & Ns & ns & ns \\
\hline HL $x$ female & $8.88 \pm 0.08$ & $3.45 \pm 0.014$ & $11.26 \pm 0.08$ & $11.86 \pm 0.11$ \\
\hline HL x male & $9.89 \pm 0.11$ & $3.63 \pm 0.02$ & $12.16 \pm 0.13$ & $12.44 \pm 0.14$ \\
\hline ML $x$ female & $9.17 \pm 0.09$ & $3.62 \pm 0.032$ & $11.71 \pm 0.09$ & $12.20 \pm 0.12$ \\
\hline ML x male & $10.1 \pm 80.14$ & $3.74 \pm 0.03$ & $12.42 \pm 0.015$ & $13.14 \pm 0.16$ \\
\hline LL $x$ female & $9.33 \pm 0.09$ & $3.29 \pm 0.014$ & $11.96 \pm 0.09$ & $12.03 \pm 0.12$ \\
\hline LL x male & $9.98 \pm 0.11$ & $3.68 \pm 0.02$ & $12.46 \pm 0.014$ & $12.68 \pm 0.15$ \\
\hline
\end{tabular}

When, $\left(^{*}\right)$ shows significant and (ns) shows no significant. HL: Highland, ML: Midland and LL: Lowland and Traits of Ws: Wing span, Bel: Beak length, Wl: wattle length, Cc: Chest circumference, Sl: Shank length, Wbt: Body weight, El: Ear length, Bl: Body length, Cl: Comb length, Cw: Comb width, Nl: Nick length, Wil: Wing length, Ww: Wattle width and Sc: Shank circumference.

\section{Conclusion and Recommendation}

In Ethiopia, the agricultural sector is a corner stone of the economic and social life of the people since they are used for generation of extra cash incomes, provision of animal protein and religious/cultural considerations. Understanding the situation of poultry rearing was crucial for improvement of poultry products and to design poultry breeding strategy. Generally chicken rearing system in the study area was mixed with crop- livestock production system using traditional management of indigenous chickens. The presences of various predators and diseases prevalence were two major economic important of chicken rearing constraints. There is diversity of indigenous chicken population and farmers' preference for specific traits that may invite to design community based genetic improvement. The study also showed that wide variations of traits considered among the indigenous chickens in the study area. The study reveals phenotypic variability which is affected by both genetic and environmental factors.

i. Poultry breeding policy which focused on selection and trait preference should be designed.

ii. Government, research and developmental organizations should give attention to village poultry sector and its development.

iii. Government should train community chicken vaccinators to provide wide spread vaccination against major poultry diseases.

iv. The finding of this study showed that there are varied indigenous chicken ecotypes in phenotypic characterization but there is not enough phenotypic characterization for indigenous chicken, Therefore studies on phenotypic characterization including egg quantity/quality together with molecular characterization need to be planned that will further clarify the genetic similarity and diversity among the ecotypes.

\section{Acknowledgements}

First and above all I would like to thank the almighty God with His Mother St. Virgin Mary for his willingness to reach at this stage; without his assistance nothing would be happened. He has unreservedly offered me during the study and all the time. I would like to express my deepest and sincere appreciation to my respected major advisor Manzoor Ahmed Kirmani (Prof.), for his unreserved advice, guidance and comments from proposal write up to submission of the final thesis write up the initial of conception to the end of this work are highly appreciated. I am very grateful to my coadvisor Meseret Molla (ASS. Prof) for her valuable comments, advice, criticism make this work complete. She shaped me to be more analytical in many aspects. Thank you very much my major advisor Manzoor Ahmed Kirmani (Prof.) and Meseret Molla (Ass prof).

I would like to express my deepest gratitude and appreciation to Ministry of Education for fully sponsoring my study and research work and Department Graduate Committee (DGC) of Animal Sciences and the School of Graduate Studies of Jimma University for their conducive learning program and provision of various services. I also wish to express my thanks to agricultural office of Awi zone, all developmental agent (DA), kebele administrations and farmers of all the study districts for their kindness, encouragement and help during data collection in who 
responded to my numerous questions with patience.

\section{References}

[1] FAOSTAT Database, 2012. Retrieved October 10, 2014, from http://faostat.fao.org/faostat/, FAO, Rome.

[2] CSA (central statistical agency). 2016/17 [2009 E. C.] livestock and livestock characteristics (private peasant holdings); agricultural sample survey volume 2, federal democratic republic of Ethiopia, Addis Ababa, Ethiopia.

[3] FAO, (Food and Agriculture Organization of the United Nations).2012.Phenotypic characterization of animal genetic resources. FAO Animal Production and Health Guidelines No. 11. Rome. [Accessed on 25. 05. 2014]. Available at http://www.fao.org/docreep/015/i2686e/i2686e00.pdf. FAO, Rome.

[4] Aberra, M. and Tegene, N., 2011. Phenotypic and morphological characterization of indigenous chicken populations in southern region of Ethiopia. Animal Genetic Resources / Resources génétiques animales / Recursos geneticos animales, 49, 19-31.

[5] Halima, H., Neser, F. W. C., van Marle-Koster, E. and De Kock, A., 2007. Phenotypic variation of native chicken populations in northwest Ethiopia. Tropical animal healthand production, 39 (7), pp. 507-513.

[6] Cochran, W. G. 1963. Sampling Techniques, 2nd Ed., New York: John Wiley and Sons, Inc.

[7] Khobondo, J. O., Okeno, T. O., Lihare, G. O., Wasike, C. B. and Kahi, A. K., 2015. The past, present and future genetic improvement of indigenous chicken of Kenya. Animal
Genetic Resources/Resources génétiques animales/Recursos geneticos animales, 55, pp. 125-135.

[8] Horst, P., 1989. Native fowl as reservoir for genomes and major genes with direct and indirect effects on the adaptability and their potential for tropically orientated breeding plans. Archive Gefluegelkunde (Germany, FR). household type and household composition on women's reproductive health outcomes in urban Uttar Pradesh, India. Decision- making, 6, 8.

[9] Addisu, G. and Aschalew, T., 2014. A Phenotypic and Genetic Characterized Indigenous Chicken Ecotypes in Ethiopia. International Journal of Genetics, 4 (1), 04-10.

[10] Mearg, F. E. A. R. G., 2016. Phenotypic characterization of local chicken ecotypes in the Central Zone of Tigray in northern Ethiopia (M.ScThesis, Jimma University).

[11] Emebet, M., Singh, H., Sisaye, T. and Johansson, A. M., 2013. Phenotypic characterization of indigenous chicken population in South West and South part of Ethiopia. Br. J. Poult. Sci, 3 (1), pp. 15-19.

[12] Eskindir, K., Tadelle D., and Banerjee, A. K. 2013. Phenotypic Characterization of Indigenous Chicken Population in Ethiopia. International Journal. Ethiopia. African Journal of Agricultural Research, 8 (11): 1014-1021.

[13] Bogale K., 2008. InSitu Characterization of Local Chicken Eco-Type for Functional Traits and Production System in Fogera District, Amhara Regional State. MSc Thesis Harmaya University, Haramaya, Ethiopia.

[14] Addisu H., 2013. Phenotypic Characterization of Indigenous Chicken Ecotypes in North Wollo Amhara Regional State. MSc Thesis, Wollo University, Wollo, Ethiopia. 